\title{
Analysis of word-formation processes in the English and Russian thematic groups "insectophones"
}

\author{
Victoria Oschepkova ${ }^{1}$, Elizaveta Razheva, ${ }^{1, *}$ \\ ${ }^{1}$ Moscow Region State University, 10A, Radio str, 105005, Moscow, Russia
}

\begin{abstract}
The article is devoted to the consideration of derivative processes in the English and Russian thematic groups "insectophones" / «инсектофоны». Due to the diversity of the compared languages, the features of word formation in the studied groups are revealed and the processes of occurrence of insectophones in the language are described. For the English language, the key methods are derivation methods such as stem composition, suffixation, back derivation and conversion. The most productive is the stem composition. For the Russian language within the framework of the studied thematic group, the leading methods can be called the same as in English with the exception of conversion. In Russian, the most common way of forming insectophones is suffixation. In both languages, insectophones formed using diminutive suffixes, which subsequently lost the meaning of subjective assessment, are identified. In compound words in English and Russian, the place of the repeating element is different (in English - in the second place, in Russian - in the first one).
\end{abstract}

\section{Introduction}

The objectives of our research are to compare the word-forming processes in the Russian and English thematic groups «инсектофоны» / "insectophones", to identify derivational processes, to clarify and systematize isomorphic and allomorphic wordforming characteristics of groups of lexical units. To designate the name of an insect, but not any name, but only onomatopoeic, that is, phonetic imitation of insect signals, lexicophonetic onomatopoeia and lexical means of imitation of an acoustic signal of an insect, we introduce the term INSECOPHONE into linguistic scientific use [1]. We regard the collection of insectophones as a THEMATIC GROUP [2].

As part of the thematic groups «инсектофоны» / "insectophones", two subgroups can be distinguished according to the time of appearance. The first group consists of basic vocabulary, ancient in origin, a long period existing in the language. The number of such tokens, both in English and in Russian, is relatively large. They represent the core of the «инсектофоны» / "insectophones" thematic groups. The second group is much smaller, it includes borrowed insectophones, mastered by the language over time. Thus, the mosquito

\footnotetext{
*Corresponding author: e.s.razheva@mail.ru
} 
token borrowed from Spanish into English retains its original form in English. As you know, the diminutive suffix -ito is typical of the Spanish language, and the insectophone mosquito means "little fly." In English, this word is used to refer to another insect - "gnat", and it loses its diminutive meaning. In Russian, the borrowed word mosquito loses the ending $-o$, that is, it changes its form under the influence of the host language. The form of the insectophone scorpion / скорпион, borrowed in English and Russian from the French language, remained unchanged.

The first group of insectophones becomes the basis for the appearance of "new" names of insects, their further differentiation, subcategorization of the species.

When differentiating insects belonging to the order of beetles in newly formed lexemes in both languages, tokens were added to the beetle component, reflecting the distinctive features of each insect - these are click beetle / жук-щелкун, boтbardier beetle / жукбомбардир, corngroundbeetle.

\section{Methodology}

Today, the question of the sound-letter correlation, relationship between the form and the meaning is very relevant in modern linguistics. This article is devoted to phonosematics which deals with this issue. The issues of phonosemantics attract the attention of many researchers $[3,4,5,6,7,8]$.

The article is a brief overview of the deep and long research in the field of the thematic group INSECTOPHONES. The procedure the authors followed for extracting insectophones was based on using many different dictionaries (English-English, RussianRussian, English-Russian, Russian-English, dictionaries of proverbs and saying, phraseological dictionaries and special etymological dictionaries).

The English thematic group "insectophones" has 55 units: bee, beetle, bedbug, billbug, breeze. Boll Weevil, bombardier beetle, bug, bumble-bee, butterfly, buzz, caddisfly, carabus, chinch, click beetle, cockroach (roach), com ground beetle, cricket. Daddy-longlegs, dragonfly, drone, Dumbledore, firefly, flea, fly, froghopper, gadfly, gnat, grasshopper

(hopper), green-fly, hornet, horsefly, humble-bee, itch mite, katydid, mayfly, midge, midget, mosquito, moth, mozzie, sandfly, sawfly, scarab, scorpion, skeeter, spider, steam, sting, termite, tick, wasp, whistling moth.

The Russian thematic group «инсектофоны» has 51 units: бабочка, блоха, букашка, вошь, гнус, жало, жигалка, жужелица, жужжало, жужжальца, жук, жук-бомбардир, жук-щелкун, журчалка, звонец, златогузка, каракурт, клещ, клоп, комар, ктырь, кузнечик, кукушка каменного шмеля, москит, мотылек, мошка, муха, немка, нехрущ, оса, пилильщик, пискунья, пчела, саранча, сверлило, сверчок, скарабей, скорпион, скрипун осиновый, термит, трещалка, трещотка, трутень, хрущ, хрущак, хрущик, цикада, шершень, шипящий таракан, шмель, щелкун.

With the help of the selected material the authors come to the idea of the concept of the insectophones and the thematic group of insectophones. Then they try to find out their common and specific derivative features.

This is of high importance not only for the sound-letter correlation but also for wordbuilding issue. Word formation deals with both the existing words as well as the newly created words. Many scientists pay attention to this phenomenon $[9,10,11,12,13]$.

The data of the research include the processes of word formation in both English and Russian thematic groups, as well as the lexemes are given as examples of these processes.

First, the processes of word formation in the English thematic group "insectophones" will be discussed. Then, the processes of word formation in the Russian thematic group «инсектофоны» will be discussed. Finally, the processes in the two languages will be compared to find some common and different features. 


\section{Word-formation processes in the English thematic group "insectophones"}

When the composition of the thematic group "insectophones" is replenished due to the internal resources of the English language, the most productive method of word formation is word-compounding (using word formation, about a third of the total composition of the thematic group - 18 units). At the heart of a compound word, two or more roots are distinguished. As the study showed, the most general model for insectophones, in which one of these roots is a free lexical morpheme and the root of the word, expressing the lexical meaning and coinciding with the stem [14]. The thematic group consists of five such units: bee, fly, beetle, hopper, bug:

- bee - bumble-bee, humble-bee,

- bug - billbug, bedbug,

- fly - butterfly, caddiesfly, dragonfly, sawfly, firefly, mayfly, green-fly, horse-fly, sandfly, gadfly,

- beetle - click beetle, corn ground beetle, bombardier beetle,

- hopper - grasshopper, froghopper.

As the structural analysis of complex insectophones shows, the most frequent is the $\mathrm{N}+$ $\mathrm{N}$ model in the studied thematic group. Very few insectophones are formed by the $\mathrm{V}+\mathrm{N}$ model (bumble-bee (bumble - verb) and Adj. + N (humble-bee (humble - adjective)).

Insectophones with the free lexical morpheme hopper represent not just complex words, but complex derived lexemes. In addition to two roots in grasshopper and froghopper insectophones, the presence of a suffix (grass + hop + er, frog + hop + er) of the producer of the action -er, a productive affix of German origin, is also noted [14].

The group of insectophones is replenished by new words formed by analogy - by copying a certain pattern, which is a lexical unit with a certain form. Thus, the grasshopper model is an insectophone froghopper. In both insectophones, the hop root, which transfers the ability of the insect to jump, serves as a sound-reflecting element. At the same time, not only the onomatopoetic root element is repeated, but the construction scheme of the token with affix is also preserved.

Insectophones with a free token beetle can be divided into two groups. The first group is completely phonetic motivated insectophones in which both roots of onomatopoeic origin are click beetle, bombardier beetle. Moreover, these English insectophones completely coincide in structure with their Russian correlates, жук-бомбардир, жук-щелкун. Тhey differ only in the sequence of the repeating element. In English, the beetle element follows the defining words click and bombardier. In Russian, a repeating element takes first place in compound words - жук-бомбардир, жук-щелкун. The second group includes the insectophone - corngroundbeetle, where the free lexical morpheme beetle has the onomatopoeic origin, and the elements of cornground are phonetically unmotivated.

Insectophones with the free lexical morpheme fly are also partially motivated. Sound is only the second element of the word - fly, reflecting the ability to fly.

Compounding in insectophones differentiates an insect by a particular, individual attribute.

The thematic group "insectophones" in the English language is replenished with the help of this type of word formation, such as suffixation, back formation and conversion. In addition to the suffix -er (skeeter, spider, froghopper, grasshopper), diminutive suffixes -ie (mozzie), -et (midget, cricket, hornet) are involved in the formation of insectophones. The method of suffixation differs from the compounding in that during the compounding there is a process of isolating, clarifying one stem with another stem, and the name of the others similar to the class is selected. With a suffix, the called is included in this class. Suffixing is the second most productive way of word formation in the English thematic group 
"insectophones" (fifteen percent of the tokens that make up the thematic group are formed by suffixing).

The replenishment of the composition of the thematic group also occurs with the help of back formation. In this way, the thematic group "insectophones" in the English language was replenished by five units, that is, nine percent. During back formation, a new word is formed from the existing one not in the form of a derivative, but in the form of a producing one. Insectophone grasshopper in modern English leveled up to hopper, insectophone cockroach in order to avoid sexual connotations was reduced to roach, bedbug, denoting a bug (bed), having lost the first member of the composite, turned into a bug, expanding the meaning to "any bug" $[15,16]$. The insectophone termite, formed from the Latin termites, has lost its ending. The insectophone, borrowed into English from the Middle French scarabeé - scarab, lost the last syllable.

Moreover, the composition of the thematic group is replenished due to conversion (a total of five such units were identified, that is, nine percent of the composition of the thematic group). The analysis shows that the most frequent model of the formation of insectophones in the English language is $\mathrm{V} \rightarrow \mathrm{N}$. Insectophone a breeze "gadfly, horsefly" comes from to breeze, a drone "drone" goes back to drone, a fly "gnat" from to fly, a sting "stinger" from to sting, a tick "mite" from to tick.

It is interesting that, despite the fact that conversion is the most productive way of word formation in English, in the analyzed thematic group it is inferior in productivity to such word formation methods as word compounding and suffixation.

\section{Word-formation processes in the Russian thematic group «инсектофроны»}

In the Russian thematic group «инсектофоны», affixation is the most productive way of word formation, and word compounding and back formation are also used.

The insectophones of the Russian language are divided into two groups according to the affixal method of word formation: suffixal and prefixal. The first and most numerous group is insectophones formed by suffixation (more than half of the composition of the thematic group). Some suffixes of the Russian language are considered primordially Russian: - щuк (-чик), -овщик, -льщик, -лк(a), -овк(a), -к(a) [17]. Accordingly, insectophones incorporating such word-forming elements also belong to the native Russian words. As the analysis of the composition of the thematic group shows, the most frequency model is the onomatopoeic / sound symbolic stem + suffix (or two suffixes):

-лк(а) - журчалка, жигалка, трещалка,

-к(а) - бабочка, букашка, мошка, немка, трещотка, хрущак, кукушка (каменного шмеля),

-льщуик - пилильщчик,

$-и \kappa-$ diminutive suffix in this case (кузнечик, хрущик),

-ек/ок - variants of one diminutive suffix (мотылек, сверчок). However, the suffix -ик compared to suffixes $-e k / o k$ is more expressive, since the end of the $e k / o k$ simply expresses a reduced appearance of the subject, and at the end of the $-u \kappa$ "one already feels a joke" and "the reduced, miniature object seems cute" [18],

-eu - a productive derivational morpheme, which in this case means a male insect (звонеи), and the female suffix corresponding to it is a female insect -ица (жужелииа). Obviously, the insectophone жужелица is formed by analogy with such tokens as тигрица, медведица, волчица, representing female animals. Only two insectophones with these suffixes were detected. The suffix - eu stands somewhat apart from the affectionatediminutive suffixes $-u k / o k / e k$. In the suffix -eu "brighter than in the suffix -uk, shades of tenderness, sympathy, humility, humiliation, contempt, familiar participation" appear [18], 
$-y \mu$ - reflects the name of the insect according to a certain attribute - the sound it produces (скрипун, щелкун, пискунья),

-ень - when a verb is added to the stem, it forms nouns with the meaning of an insect, characterized by an action called a word-forming verb (трутень, шершень),

-ель - the unproductive suffix, however, one of the most sonorous and expressive in the Russian language, has survived from the 14th - 18th centuries (шмель),

$-\pi(o)$ - another unproductive suffix in the composition of insectophones of the Russian language (жало, жужжало, сверлило), because "in the modern language, the suffix -л(о) is alive and productive only in a morphologically determined position (in combination with the verbal stems ending in $-a$ and $-и$ : -ало, -ило) "[18]. The suffix $-л(о)$, denoting the name of the insect, forms nouns from verbs denoting the sounds of insects. Despite the fact that this suffix is considered "dead", we noted three insectophones in which it is present. Perhaps this is due to the fact that "a wide range of use of such entities in professional dialects" [18].

\section{Results}

Now let's make the comparative word-formation analysis of the studied thematic groups.

In the Russian thematic group "insectophones" of the twelve suffixes involved in the formation of insectophones, we noted four diminutive suffixes (three diminutive and caressing suffixes: $-u \kappa,-o k$, $-e k$ and one affectionate and derogatory suffix), in the English thematic group "insectophones" - two diminutive suffixes out of three (-ie, et). Tokens formed using such suffixes are considered "forms of subjective assessment" [18]. Obviously, such a variety of suffixes of subjective assessment in the Russian and English thematic group "инсектофоны" / "insectophones" is associated with the small size of insects, and in the process of nomination this feature was taken into account, along with the sounds made by these creatures. However, insectophones with such suffixes are not perceived as diminutive, affectionate and derogatory by native speakers, insectophones are perceived only as the names of certain insects. Thus, the diminutive meaning of the form erased, disappeared.

The second group includes insectophones formed by the prefixal method using the negative prefix не-. This group included only one insectophone нехрущ, that is, the insect's ability to make sounds is denied in the insectophone itself.

The thematic group «инсектофоны» in the Russian language is replenished not only with the help of affixation, but also with the help of stem composition. There are only three such insectophones, which is about six percent of the total number of insectophones in the Russian language. Composites of a compound word can be divided into:

1) neutral, that is, formed with the help of two stems without a connecting morpheme, by a simple juxtaposition of the stems. These are insectophones: жук-бомбардир, жукщелкун. As the analysis of the structure of these two complex insectophones shows, they are formed according to the model noun + noun $[\mathrm{N}+\mathrm{N}]$,

2) morphological, that is, composites are connected using connecting elements, connecting service morphemes. We have identified one such insectophone - златогузка. The two stems of злат- and гузк- are connected by a connecting morpheme -о-. The Insectophone structure is adj. + noun $[\mathrm{Adj}+\mathrm{N}]$. Therefore, there is an attributive form.

In the Russian language, insectophones formed with the use of phrases are not just compound words, but compound words with affixations (жук-щелк+yн, жукбомбард + ир, злат-о-гуз $+\kappa(a))$.

Furthermore, unlike the English language, where the repeating composite takes second place in complex words (click beetle, bombardier beetle), in Russian it takes the first place (жук-щелкун, жук-бомбардир). We dare to suggest that the sequence of composites in 
complex insectophones of both languages depends on the actual division of speech - a concept designed to describe the functional components of a statement: the topic - the starting point of the message and the comment - the part being communicated (new). It is known that in English, the comment is most often located at the beginning of a statement, in Russian, at the end. Communicative dynamism grows in time for the words that determine the type of insect, in this case a beetle (бомбардир, щелкун, click, bombardier) comment. Beetle / жyк is a theme in both languages. For the addressee, it is more important to obtain information not about the insect order (the order of beetles), but about the type of insect that differentiates it from the rest of the representatives of this order.

The composition of the thematic group is also replenished due to back formation (four percent of the composition of the thematic group). These are borrowed insectophones термит and москит, having lost their endings, and assimilated in Russian.

\section{Conclusion}

In English, the analyzed thematic group is replenished with the help of affixless word formation. In Russian, insectophones formed by conversion were not detected. This is understandable, since conversion is not the leading way of word formation in the Russian language.

Thus, in the English language, four methods for the formation of insectophones are revealed: compounding, suffixation, back formation and conversion. The most productive is the stem composition. In the Russian language there are the same word-formation methods, with the exception of conversion. In Russian, the most common way of forming insectophones is suffixation.

In both languages, insectophones formed using diminutive suffixes, which subsequently lost the meaning of subjective assessment, were identified. In compound words in English and Russian, the place of the repeating element is different (in English - in the second place, in Russian - in the first one).

\section{References}

1. E.S. Razheva, Complex lexical-semantic and linguoculturological analysis of the thematic group "insectophones": based on the material of English and Russian languages: dissertation ... candidate of philological Sciences (Moscow, 2013)

2. E.S. Razheva, Bulletin of the Moscow state regional University. Series: Linguistics 3, 64 (2018)

3. J. Auracher, S. Albers, Y. Zhai et al, Discourse processes 48(1), 1 (2011)

4. M.V. Danilchuk, Newsletter of the Herzen State Pedagogical University of Russia 181, 29 (2016)

5. M. Magnus, What's in a word? Studies in phonosemantics PhD dissertation (Trondheim, University of Trondheim, 2001) http://www.trismegistos.com/Dissertation/dissertation.pdf

6. C.E. Osgood, The measurement of meaning 12(3), 225 http://dx.doi.org/10.1037/h0070931

7. E. Sapir, A study in phonetic symbolism. Journal of experimental psychology (1929)

8. R. Wagner, The psychological reality of iconism and its impact on the English language, https://www.academia.edu/7038443/The

9. L. Bauer, English Word Formation (Cambridge, Cambridge University Press, 1983) 
10. D.A. Crystal, Dictionary of Linguistics and Phonetics $6^{\text {th }}$ ed (Oxford, Blackwell Publishing, 2003)

11. M. Perkles, Compounds in English and Russian: A Comparative Analysis. Master Thesis (Vienna University, 2008)

12. N. Snyder, R. Thomson, Formation of Words: Processes and Rules (California, Santa Monica College, 2006)

13. J.V. Williamson, A Phonological and Morphological Study of English (Alabama, Alabama State University, 2004)

14. E.M. Dubenets, Modern English. Lexicology: a Handbook for students. human. higher educational (M., SPb., GLOSSA/KARO, 2004)

15. ABBYY Lingvo.Pro, http://lingvopro.abbyyonline.com/en

16. Multitran dictionary: Multitran system for translators, http://www.multitran.ru/c/m.exe?a=1\&SHL=1

17. L.L. Kasatkin, E.V. Klobukov, P. Krysin, Russian language: textbook for stud. higher. PED. studies'. institutions (Moscow, Ed. center "Academy", 2001)

18. V.V. Vinogradov, Russian language (Grammatical teaching about the word): studies. manual for universities (M., Higher. SHK, 1986) http://www.slovari.ru/default.aspx?s=0\&p=170 